\title{
Validated high-performance liquid chromatographic method for the standardisation of Ptychopetalum olacoides Benth., Olacaceae, commercial extracts
}

\author{
Renata Colombo, ${ }^{*}, 1$ Andrea N. de L. Batista, ${ }^{1}$ Giovani C. C. Bomfim, ${ }^{1}$ Rosilene C. R. Burgos, ${ }^{1}$ \\ Alberto J. Cavalheiro, ${ }^{1}$ Vanderlan da Silva Bolzani, ${ }^{1}$ Dulce Helena S. Silva, ${ }^{1}$ \\ Maria Célia H. Reimberg ${ }^{2}$ \\ ${ }^{1}$ Instituto de Química, Universidade Estadual Paulista, R. Francisco Degni, s/n, Bairro Quitandinha, \\ 14800-900 Araraquara-SP, Brazil, \\ ${ }^{2}$ Anidro do Brasil Extrações Ltda, Caixa Postal 254, 118603-970 Botucatu-SP, Brazil.
}

\begin{abstract}
RESUMO: "Validação de método de cromatografia líquida de alta performance para padronização de extratos comerciais de Ptychopetalum olacoides Benth., Olacaceae". Ptychopetalum olacoides Benth., Olacaceae, popularmente conhecida como marapuama, muirapuama ou miriantã, é uma espécie nativa da região da Amazônia do Brasil. Extratos das cascas da planta são tradicionalmente usados por suas propriedades estimulantes e afrodisíacas, e frequentemente comercializados como constituinte de uma grande variedade de formulações fitoterápicas. O fracionamento por coluna cromatográfica aberta seguida por CLAE-UV/PAD das cascas do caule de três extratos comerciais de P. olacoides permitiram o isolamento de três substâncias comuns em todos os extratos analisados. Os compostos foram identificados por RMN como ácido vanílico, ácido protocatecuíco e teobromina. $\mathrm{O}$ ácido vanílico foi utilizado como marcador fitoquímico para $P$. olacoides e empregado como padrão externo no desenvolvimento e validação de um método de análise qualitativo e quantitativo rápido por CLAE. O valor da recuperação do método desenvolvido foi de $99,02 \%$ e os valores de LOD e LOQ foram 0,033 e 0,11 mg. $\mathrm{L}^{-1}$, respectivamente. $\mathrm{O}$ método descrito poderá ser empregado para a padronização de plantas, extratos ou fitoterápicos comercializados como marapuama.
\end{abstract}

Unitermos: CLAE-UV/PAD, RMN, Ptychopetalum olacoides, marapuama, ácido vanílico.

\begin{abstract}
Ptychopetalum olacoides Benth., Olacaceae, popularly known as marapuama or muirapuama or miriantã, is a species native to the Amazonian region of Brazil. Extracts of the bark of the plant have been used traditionally for its stimulating and aphrodisiac properties and currently commercialised by the herbal industry as constituents in a wide range of phytomedicines. Fractionation by open column chromatography followed by preparative HPLC-UV/PAD of the stem bark and of three commercial extracts of $P$. olacoides allowed the isolation of three components that were common to all extracts analysed, and these were identified by NMR to be vanillic acid, protocatechuic acid and theobromine. Vanillic acid, which has been proposed as a phytochemical marker for P. olacoides, was employed as an external standard in the development and validation of a rapid qualitative and quantitative HPLC assay for the analyte. The recovery values of the developed method were $99.02 \%$ and the LOD and LOQ values were 0.033 and $0.11 \mathrm{mg} . \mathrm{L}-1$, respectively. The described method may be applied to the standardization of herbs, extracts or phytomedicines commercialised as marapuama.
\end{abstract}

Keywords: HPLC-UV/PAD, NMR, Ptychopetalum olacoides, marapuama, vanillic acid.

\section{INTRODUCTION}

Decoctions of the root and stem bark of Ptychopetalum olacoides Benth., Olacaceae, have been used in folk medicine for their aphrodisiac, appetite modulator and anti-tremor properties. Additionally, the plant is claimed to act as a nerve tonic by promoting recovery of cognitive and motor functions after brain injuries (including strokes) and cognition improvement (particularly alertness and memory) in the elderly (Elisabetsky et al., 1992; Drewes et al., 2003).

The traditional uses of $P$. olacoides have been 
extensively exploited by herbal industries in several American and European countries, and the native herb or its extracts are constituents of various phytomedicines supplied in the form of pills, tinctures, tablets, multivitamin supplements or compound extracts (Silva et al., 2002; Siqueira et al., 2003, 2007). The plant is also a component of the medication Catuama ${ }^{\circledR}$, which is widely used in several parts of Brazil as a general tonic and to alleviate physical and mental fatigue (Antunes et al., 2001). The pharmacological properties of such tonics have been elucidated and discussed (Siqueira et al., 2003), while a number of experimental and clinical studies carried out on extracts of $P$. olacoides have validated their medicinal applications (Drewes et al., 2003; Siqueira et al., 2003, 2007; Silva et al 2007). In contrast, little is known concerning the phytochemistry of the species. Analyses of lipophilic extracts of the plant have indicated the presence of terpenes (Auterhoff \& Momberger, 1971; Bucek et al., 1987; Ito et al., 1995), of fatty acids (Toyota et al., 1979), of sterols and of the xanthines caffeine and theobromine (Montrucchio, 2005). Spectrophotometric methods based on total flavonoid content (determined as rutin) have been proposed for the standardisation of the commercial herb and of phytomedicines derived therefrom (Baby et al., 2005; Baby et al., 2006).

In the present study, the HPLC-UV/PAD profiles of bark and commercial extracts of $P$. olacoides were examined, and a protocol for the isolation and purification of three compounds present in all of the analysed extracts was elaborated. The common components were identified by NMR as vanillic acid, protocatechuic acid and theobromine, the former of which has been proposed as a phytochemical marker for P. olacoides. With the objective of formulating an efficient methodology for the standardization of phytomedicines containing $P$. olacoides, vanillic acid was employed as an external standard in the development and validation of a rapid and efficient, qualitative and quantitative HPLC assay for the analyte. The method may be applied in the determination of the reproducibility, efficacy, safety and quality of herbs, extracts or phytomedicines commercialised as marapuama.

\section{MATERIAL AND METHODS}

\section{Plant material and extracts}

Three industrial extracts and a sample of stem bark (air-dried at $c a .40{ }^{\circ} \mathrm{C}$ and stored at room temperature for six months) of Ptychopetalum olacoides Benth., Olacaceae, were provided by Anidro do Brasil Extrações Ltda., Botucatu-SP, Brazil. The plant material was collected in Nhamundá-AM, Brazil, the specimens of plant were identified by Dr. Inês Cordeiro (Instituto Botânico de São Paulo-SP, Brazil) and a voucher was deposited in the herbarium of the Instituto Botânico de São Paulo with the identification code SP373338. The commercial extracts supplied were: (1) soluble dry extract-code 20669, (2) dry extract F\&C-code 21621, and (3) fluid extract-code 20225, all derived from macerated bark.

\section{Materials}

HPLC-grade acetonitrile and methanol were supplied by J. T. Baker (Philipsburg-PA, USA), whilst analytical grade acetic acid was from Synth (DiademaSP, Brazil). Water was purified using a Milli-Q apparatus (Millipore, São Paulo-SP, Brazil). Silica octadecyl $\left(\mathrm{C}_{18}\right)$ (43-60 $\mu \mathrm{m}$ particle size) were purchased from Merck (Rio de Janeiro-RJ, Brazil). The standard employed in the analyses was vanillic acid (97\% pure) that had been isolated in the Instituto de Química, Universidade Estadual Paulista, Araraquara-SP, Brazil.

\section{Isolation of the common components of $P$. olacoides extract}

A sample $(4.0 \mathrm{~g})$ of the dry extract F\&C (code $21621)$ derived from the bark of $P$. olacoides was sonicated with $80 \mathrm{~mL}$ of $40 \%$ aqueous methanol for $30 \mathrm{~min}$ at room temperature. The resulting extract was concentrated in a rotary evaporator and dried to constant weight under a nitrogen flow. An aliquot $(3.5 \mathrm{~g})$ of the residue was dissolved in $10 \mathrm{~mL}$ of methanol-water (20:80 $\mathrm{v} / \mathrm{v}$ ) and fractionated in an open chromatographic column $(11.0 \times 2.5 \mathrm{~cm}$ i.d.) packed with C18 silica gel $(2 \mathrm{~g})$ and eluted with a step gradient comprising $200 \mathrm{~mL}$ each of methanol-water mixtures $(15: 85,30: 70 ; 35: 65 ; 50: 50$; $70: 30 \mathrm{v} / \mathrm{v})$ and finally with pure methanol $(200 \mathrm{~mL})$. Fraction 2, which eluted with $30 \%$ aqueous methanol, was purified by preparative HPLC using a Shimadzu (Kyoto, Japan) LC-10-AVP chromatograph equipped with a model SPD-10A VP UV detector (set to record at $254 \mathrm{~nm}$ ), a model FRC-10ASIL-10AF fraction collector and an LC workstation for data collection and processing. Separation was carried out on a Phenomenex (TorranceCA, USA) Luna $\mathrm{C}_{18}$ column ( 250 x $21.2 \mathrm{~mm}$ i.d.; $10 \mu \mathrm{m}$ particle size; $100 \AA$ pore size) eluted isocratically with $0.1 \%$ acetic acid in water-acetonitrile $(90: 10 \mathrm{v} / \mathrm{v})$ in 20 min at a flow rate of $20 \mathrm{~mL} \cdot \mathrm{min}^{-1}$.

\section{Structural characterization of the common components of $P$. olacoides extract}

The common components (1-3) of the extract were eluted from the HPLC at $6.1,8.2$ and $17.9 \mathrm{~min}$, respectively. Eluate associated with each of these component was collected, concentrated by rotary evaporation, dried to constant weight in a desiccator under nitrogen, and dissolved in $\mathrm{CH}_{3} \mathrm{OH}-d_{6}(\mathbf{1})$ or DMSO- $\left.d_{6}\right)(\mathbf{2}$ and 3) for NMR analysis. The NMR experiments were 
carried out using a Varian (Harbor City-CA, USA) model 11.7 T INOVA-500 spectrometer operating at $500 \mathrm{MHz}$ $\left({ }^{1} \mathrm{H}\right)$ and $126 \mathrm{MHz}\left({ }^{13} \mathrm{C}\right)$. Spectra were assigned using data obtained from $g \mathrm{HMQC}$ and $g \mathrm{HMBC}$ experiments, whilst multiplicities were determined with the aid of gCOSY. The respective deuterated solvent was employed as the internal standard for each analyte.

\section{Preparation of samples for analytical HPLC analysis}

Samples (ca. $0.50 \mathrm{~g}$ ) of soluble dry extract (code 20669) and dry extract F\&C (code 21621) were weighed accurately and sonicated with $10 \mathrm{~mL}$ of methanol-water $(40: 60 \mathrm{v} / \mathrm{v})$ for $30 \mathrm{~min}$ at room temperature. The resulting extracts were filtered and the final volume adjusted to 10.0 $\mathrm{mL}$ with methanol-water $(40: 60 \mathrm{v} / \mathrm{v})$, using a volumetric flask. The extract solutions were filtered through $0.22 \mu \mathrm{m}$ Millex membranes (Millipore, Bedford-MA, USA) and aliquots $(20 \mu \mathrm{L})$ assayed by HPLC. A sample $(4 \mathrm{~mL})$ of commercial fluid extract (code 20225) was diluted to 10 $\mathrm{mL}$ with methanol-water $(40: 60 \mathrm{v} / \mathrm{v})$, filtered through a $0.22 \mu \mathrm{m}$ Millex membrane and an aliquot $(20 \mu \mathrm{L})$ assayed by HPLC.

\section{Analytical HPLC conditions}

During initial studies the profile of bark and of commercial extracts of $P$. olacoides were obtained using a Phenomenex Luna phenyl-hexyl column and a mobile phase of $1 \%$ aqueous acetic acid-acetonitrile with linear gradient elution from 5 to $100 \%$ acetonitrile in $40 \mathrm{~min}$ at a flow rate of $1.0 \mathrm{~mL} \cdot \mathrm{min}^{-1}$. Optimisation experiments established better chromatographic conditions to analytical separation of components with a shorter run time. Analytical separations were performed using a Waters (Milford-MA, USA) Alliance model 2795 liquid chromatographic system equipped with a model 996 PAD and running Empower Pro software (version 5.0, 2002). Separations were carried out on a Phenomenex Luna phenyl-hexyl column (250 x $4.6 \mathrm{~mm}$ i.d.; $5 \mu \mathrm{m}$ particle size; $100 \AA$ pore size), protected by a Phenomenex phenyl guard column $(4.0 \times 3.0 \mathrm{~mm}$ i.d.; $5 \mu \mathrm{m}$ particle size; $100 \AA$ pore size) at room temperature. The mobile phase $(\mathrm{pH}=3.21)$ consisted of $0.1 \%$ acetic acid in water (solvent A) and acetonitrile (solvent B) delivered at an isocratic mode $(13 \% \mathrm{~B})$ and a flow rate of $1.0 \mathrm{~mL} \cdot \mathrm{min}^{-1}$. The sample injection volume was $20 \mu \mathrm{L}$. Chromatograms were monitored at $261 \mathrm{~nm}$ ( $\lambda_{\max }$ of vanillic acid) and UV spectra associated with the individual peaks were recorded in the range 200-400 $\mathrm{nm}$. Data were processed using Waters Empower Pro ${ }^{\circledR}$ version 5.0.

\section{Method validation}

Specificity for vanillic acid was determined from the peak purity data derived from the PAD, in association with the software resource provided by the LC workstation, for vanillic acid eluting from the HPLC. The external standard method was utilised to construct the calibration curve for vanillic acid measured at a wavelength of $261 \mathrm{~nm}$. A stock solution of standard was prepared by weighing $7.8 \mathrm{mg}$ of vanillic acid (purity $97 \%)$ and dissolving in $10 \mathrm{~mL}$ of methanol-water (40:60 $\mathrm{v} / \mathrm{v}$ ) obtained a final concentration of $756.6 \mathrm{mg} . \mathrm{L}^{-1}$. Five additional standard solutions of vanillic acid with concentrations 302.6, 151.3, 75.66, 30.26 and 7.566 mg. $\mathrm{L}^{-1}$ were prepared by appropriated dilution of the stock solution. An aliquot $(20 \mu \mathrm{L})$ of the six standard solutions were injected into the HPLC, each in triplicate, and the regression equation and linearity factors determined.

Repeatability was estimated by assaying solutions containing three different concentrations of extracts (equivalent to $12.0,65.0$ and $495.0 \mathrm{mg} . \mathrm{L}^{-1}$ of total vanillic acid), each analysis being carried out in triplicate by the same operator on the same day. Intermediate precision was determined by analysing, in triplicate, one of the solutions employed in the repeatability test on two consecutive days and by another operator. Reproducibility was examined in another laboratory by carrying out the analysis on a Shimadzu LC-10-AVP instrument equipped with a model SIL-10AF auto sampler and a model SPD10A VP UV-VIS detector together with the Phenomenex analytical column system described above. A second stock solution of standard was prepared by weighing $6.7 \mathrm{mg}$ of vanillic acid (purity 97\%) and dissolving in $10 \mathrm{~mL}$ of methanol-water $(40: 60 \mathrm{v} / \mathrm{v})$ obtained a final concentration of $649.9 \mathrm{mg} . \mathrm{L}^{-1}$. Four additional standard solutions of vanillic acid with concentrations 324.9, 65.00, 26.00 and $2.600 \mathrm{mg} . \mathrm{L}^{-1}$ were prepared by appropriated dilution of the stock solution. A separate calibration curve was constructed by analyzing the five solutions of vanillic acid described above. The same solution employed in the repeatability test was reanalysed (triplicate) in the second laboratory in order to determine the reproducibility.

Accuracy of the method was determined by analysing the percentage recoveries of the vanillic acid. The samples were spiked with three different amounts of vanillic acid standard prior to extraction. The spiked samples were extracted in triplicate and analysed. The obtained average contents of the vanillic acid were used as the actual values in order to calculate the spike recoveries (Anvisa, 2003; ICH, 1994).

Precision (RSD\%) and accuracy (E\%) were estimated from the mean calculated concentration (C), standard deviation (SD) and spiked concentration (SC) values obtained from the intra- and inter-day assays according to the equations $\mathrm{RSD} \%=\mathrm{SD} \times 100 / \mathrm{C}$ and $\mathrm{E}(\%)$ $=\mathrm{C} \times 100 / \mathrm{SC}$, respectively (Anvisa, 2003; United States Phamacopeial, 2007). The limits of detection (LOD) and quantification (LOQ) were calculated on the basis of signal-to-noise ratios $(\mathrm{S} / \mathrm{N})$ of 3 and 10 , respectively. The noise level was measured during the analysis of a 
sample and involved a portion of the chromatogram that was separate from the region containing the vanillic acid peak. Robustness was investigated by carrying out assays under slightly altered chromatographic conditions involving different flow rates of the mobile phase $(0.9$ and $\left.1.1 \mathrm{~mL} \cdot \mathrm{min}^{-1}\right)$, different $\mathrm{pH}$ values of the mobile phase ( $\mathrm{pH} 2.76$ and 3.37), different compositions of the mobile phase (12\% and $14 \% \mathrm{~B})$, and different batches of the phenyl-hexyl column (lot numbers 5296-24 and 5296-26).

\section{RESULTS AND DISCUSSION}

HPLC profiles of Ptychopetalum olacoides Benth., Olacaceae, extracts

Each of the extracts analysed displayed a similar chromatographic profile revealing several major components and a number of minor peaks (Figure 1). On the basis of these profiles, dry extract F\&C (code 21621) was fractionated by open column chromatography over C18 silica gel and three compounds, which were present in all of the extracts, were subsequently separated by preparative HPLC and isolated in the form of light yellow amorphous powders.

\section{Structural elucidation of common components of $P$. olacoides extracts}

The structures of the three common compounds were determined by NMR analysis and confirmed by comparison with spectral data available in the literature (Chang et al., 2000; Choi et al., 2005; Dogasaki et al., 2002). The components were identified as vanillic acid (1), protocatechuic acid (2) and theobromine (3), and their spectral details are shown below.

Vanillic acid (1): ${ }^{1} \mathrm{H}-\mathrm{NMR}\left(500 \mathrm{MHz}, \mathrm{CH}_{3} \mathrm{OH}-d_{6}\right) \delta_{\mathrm{H}} 7.57$ $(1 \mathrm{H}, d, J=2.0 \mathrm{~Hz}, \mathrm{H}-2), 7.54(1 \mathrm{H}, d d, J=8.0$ and $2.0 \mathrm{~Hz}$,
$\mathrm{H}-6), 6.82(1 \mathrm{H}, d, J=8.0 \mathrm{~Hz}, \mathrm{H}-5), 3.89\left(3 \mathrm{H}, s, \mathrm{H}_{3} \mathrm{CO}-3\right)$; ${ }^{13} \mathrm{C}$ NMR $\left(126 \mathrm{MHz}, \mathrm{CH}_{3} \mathrm{OH}-d_{6}\right) \delta_{\mathrm{C}} 172.1\left(\mathrm{CO}_{2} \mathrm{H}\right), 152.6$ (C-4), 148.5 (C-3), 124.9 (C-1), 115.7 (C-5), 114.0 (C-2), $56.4\left(\mathrm{H}_{3} \mathrm{CO}-3\right)$.

Protocatechuic acid (2): ${ }^{1} \mathrm{H}$ NMR $\left(500 \mathrm{MHz}, \mathrm{DMSO}-d_{6}\right)$ $\delta_{\mathrm{H}} 7.34(1 \mathrm{H}, d, J=2.0 \mathrm{~Hz}, \mathrm{H}-2), 7.29(1 \mathrm{H}, d d, J=8.0$ and $2.0 \mathrm{~Hz}, \mathrm{H}-6), 6.78(1 \mathrm{H}, d, J=8.0 \mathrm{~Hz}, \mathrm{H}-5) ;{ }^{13} \mathrm{C}$ NMR $(126$ $\left.\mathrm{MHz}, \mathrm{DMSO}-d_{6}\right) \delta_{\mathrm{C}} 167.5\left(\mathrm{CO}_{2} \mathrm{H}\right), 150.0(\mathrm{C}-4), 144.8$ (C-3), 121.8 (C-1 and C-6), 116.5 (C-2), 115.0 (C-5).

Theobromine (3): ${ }^{1} \mathrm{H}$ NMR $\left(500 \mathrm{MHz}\right.$, DMSO- $\left.d_{6}\right) \delta_{\mathrm{H}} 11.05$ $(1 \mathrm{H}, b r s, \mathrm{NH}-1), 7.94(1 \mathrm{H}, s, \mathrm{H}-8), 3.84\left(3 \mathrm{H}, s, \mathrm{H}_{3} \mathrm{CN}-7\right)$, $3.33\left(3 \mathrm{H}, s, \mathrm{H}_{3} \mathrm{CN}-3\right) ;{ }^{13} \mathrm{C} \mathrm{NMR}\left(126 \mathrm{MHz}, \mathrm{DMSO}-d_{6}\right) \delta_{\mathrm{C}}$ 154.9 (C-6), 151.0 (C-2), 149.8 (C-4), 142.8 (C-8), 107.1 (C-5), $30.1\left(\mathrm{H}_{3} \mathrm{CN}-7\right), 28.4\left(\mathrm{H}_{3} \mathrm{CN}-3\right)$.

\section{Elaboration and validation of the HPLC method}

The elution program associated with the original HPLC method was optimised in order to develop a rapid and efficient, qualitative and quantitative assay for the potential phytochemical marker vanillic acid in the herb and commercial extracts of P. olacoides. Following the isolation and purification of component from P. olacoides extracts, the vanillic acid was used as an external standard for the validation of the optimised chromatographic procedure. The purity of the vanillic acid was determined by normalisation of the peak areas detected by HPLCPAD (Wang et al., 2005; Bebrevska et al., 2007) and from impurity signals detected in the NMR spectra. The chromatographic profiles of extracts of P. olacoides obtained using the developed and validated method is shown in Figure 2. The resolution indexes of vanillic acid peak in relation of its two adjacent peaks (A and B) are presented in Table 1.

Validation of specificity of the analytical method was confirmed from the purity angle and the purity threshold of $\mathbf{1}$ obtained using the PAD workstation

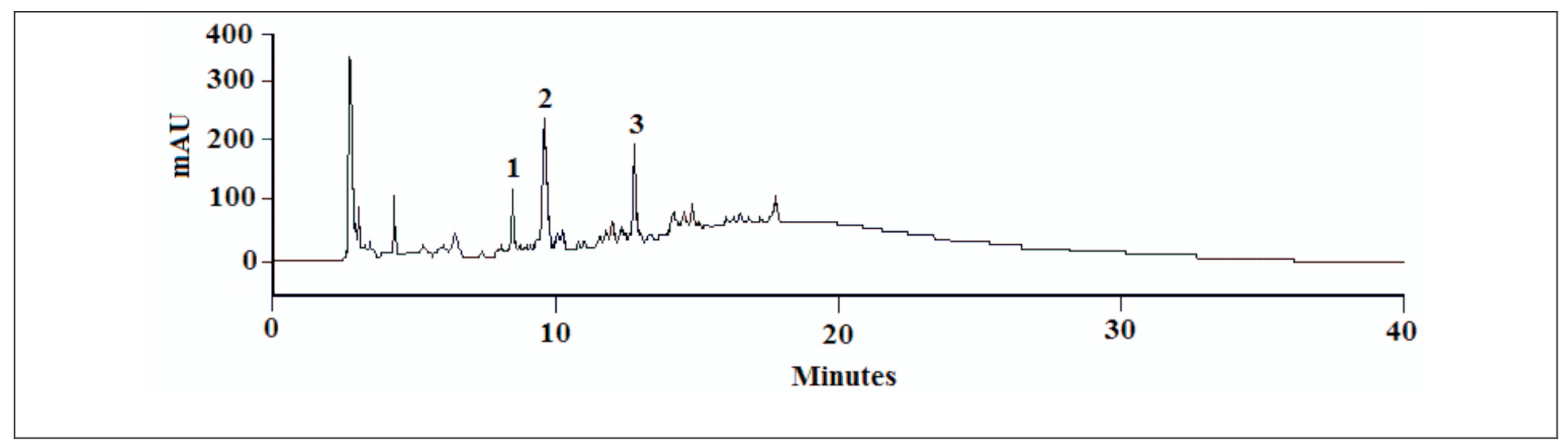

Figure 1. Representative HPLC-UV/PAD chromatographic profile of bark and commercial extracts of P. olacoides showing peaks corresponding to the isolated standards vanillic acid (1), protocatechuic acid and (2) and theobromine (3). Chromatographic conditions: Phenomenex Luna phenyl-hexyl column $(250$ x $4.6 \mathrm{~mm}$ i.d.; $5 \mu \mathrm{m})$; linear gradient elution with $0.1 \%$ acetic acid in water (solvent A) and acetonitrile (solvent B) from 5 to $100 \% \mathrm{~B}$ in $40 \mathrm{~min}$ at a flow rate of $1.0 \mathrm{~mL} . \mathrm{min}^{-1}$; UV detection at 254 nm. 
<smiles>COc1cc(C(=O)O)ccc1O</smiles>

1<smiles>O=C(O)c1ccc(O)c(O)c1</smiles>

2<smiles>Cn1c(=O)c2c(ncn2C)n(C)c1=O</smiles>

3 software resource for the standard analyte and for each of the extracts assayed. The calibration curve for 1 constructed with the UV detector set at $261 \mathrm{~nm}$ was linear in the range $756.6-7.566 \mathrm{mg} . \mathrm{L}^{-1}$ with a regression equation of $y=19000 x+25200$, a correlation coefficient (r) of 0.9999 , and a coefficient of variation of $<2 \%$ for triplicate analyses (Figure 3 ).

In the analysis of the accuracy of the method, the recoveries $(\mathrm{E} \%)$ of vanillic acid from spiked extract solutions were $99.25,98.88$ and $98.93 \%$ in respect of each of the three concentrations analysed. In terms of the determined $\mathrm{RSD} \%$, the repeatability of the method was $0.03,0.46$ and $0.47 \%$, respectively, for the three different concentrations analysed. The average precision $\mathrm{RSD} \%$ was $0.32 \%$.

The reproducibility of the method was examined in two different laboratories. In the second laboratory, a new calibration curve was constructed with 1 as external standard (Figure 5). The response of the UV detector at $261 \mathrm{~nm}$ was found to be linear in the range 649.9 to $2.600 \mathrm{mg} . \mathrm{L}-1$ with a regression equation of $\mathrm{y}=16780 \mathrm{x}+$ 4353.2, an r value of 0.9999 and a coefficient of variation of $<2 \%$ for triplicate analyses. The RSD $\%$ of the results between the two laboratories was $0.71 \%$.

The LOD and LOQ values of the developed method were 0.033 and $0.11 \mathrm{mg} . \mathrm{L}-1$, respectively. The tests of robustness revealed that the method was insensitive to $\mathrm{pH}$ variation within the range 2.76 to 3.37 and to flow rates changes between 0.9 to $1.1 \mathrm{~mL} . \mathrm{min}-1$ and using different batches of chromatographic columns. No significant variations (RSD $0.70 \%$ ) were found between the results of analyses conducted. The method was, however, qualitatively and quantitatively sensitive to small variations in the composition of the mobile phase.

The validated method was suitable for the quantitative analysis of vanillic acid in three different P. olacoides commercial extracts sold as Marapuama in the Brazilin market. Vannillic acid in all samples was confirmed by comparation of the retention time and UV spectra. The results are given on Table 2 .

In conclusion, while various studies have confirmed the pharmacological activities of $P$. olacoides, much less attention has been given to the standardization of assay methods for the commercial herb or extracts and phytomedicines derived therefrom. With regard to the phytochemical analysis of the species, some reports are available but they chiefly deal with the constituents of the oil or of lipophilic extracts. In the present study, a simple and efficient method has been developed for the isolation of pure vanillic acid, protocatechuic acid and theobromine from bark tissue. Additionally, a rapid and fully validated HPLC method, using vanillic acid as a potential phytochemical marker, has been developed for the analysis of industrial extracts, commercial phytomedicines and herbs sold as marapuama in Brazil. On the basis of the isolation method described, it is possible that protocatechuic acid and theobromine might also be to be applied as phytochemical markers.

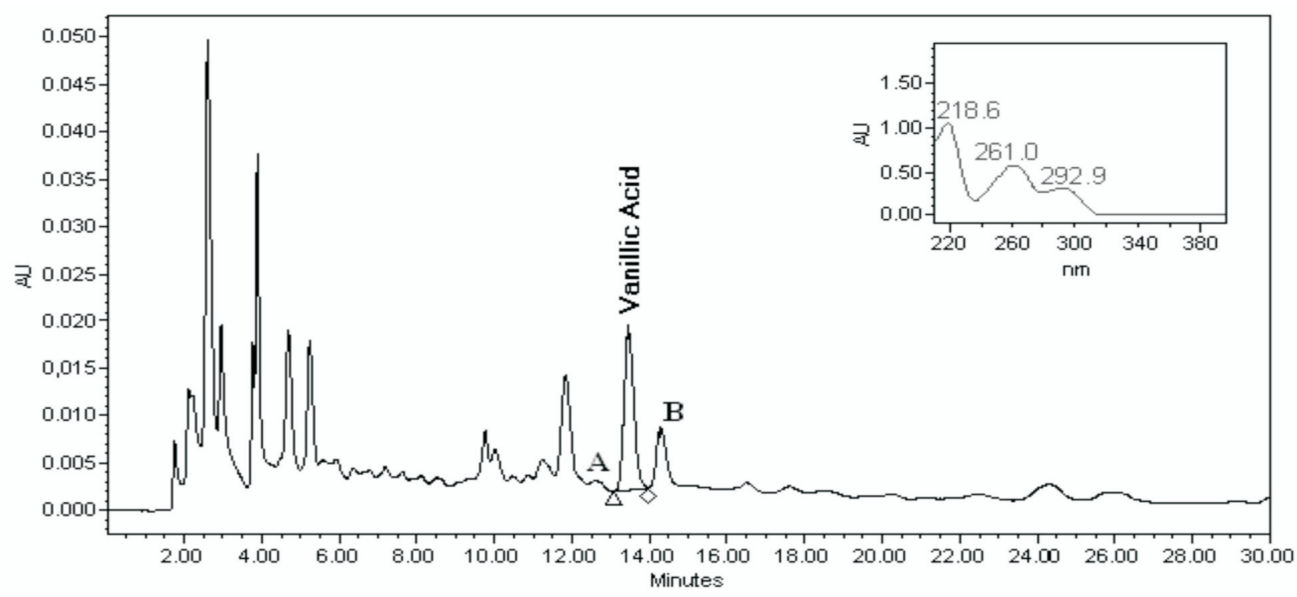

(a) 


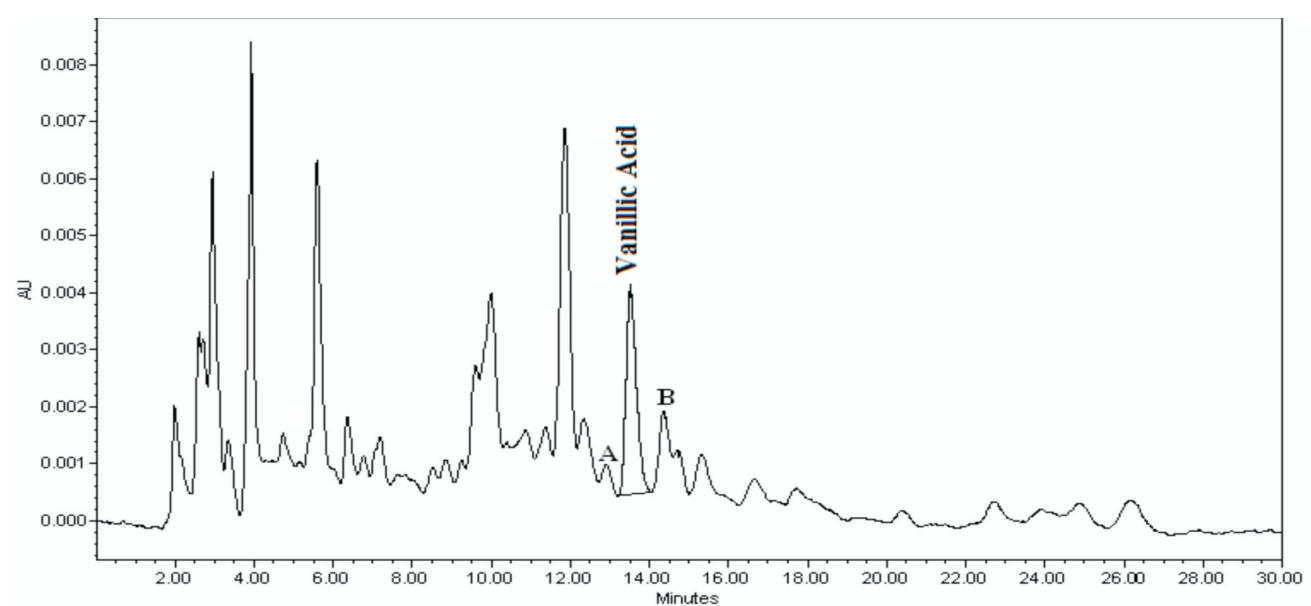

(b)

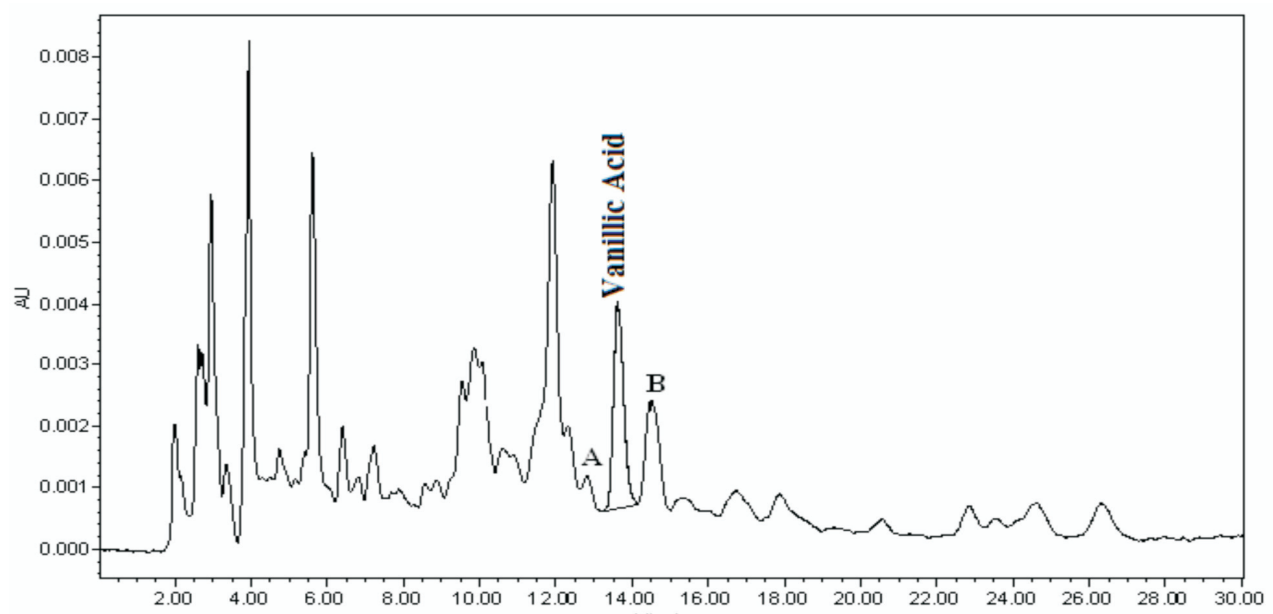

(c)

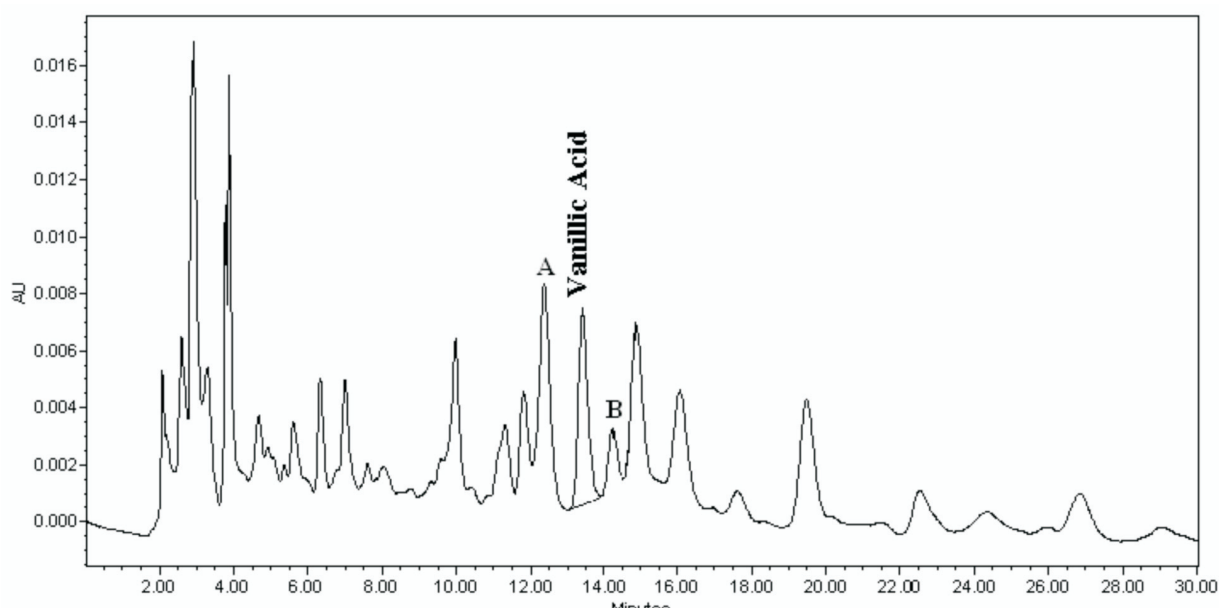

(d)

Figure 2. HPLC-UV/PAD chromatograms of extracts of $P$. olacoides showing (a) commercial water soluble dry powder extract, with the on-line UV spectrum of vanillic acid displayed as an insert, (b) commercial fluid extracts, (c) dry extract F\&C and (d) bark extract. Chromatographic conditions: Phenomenex Luna phenyl-hexyl column $(250$ x $4.6 \mathrm{~mm}$ i.d.; $5 \mu \mathrm{m})$; isocratic elution with $0.1 \%$ acetic acid in water $(87 \%)$ and acetonitrile $(13 \%)$ at a flow rate of $1.0 \mathrm{~mL} \cdot \mathrm{min}^{-1}$; UV detection at $261 \mathrm{~nm}$. 
Table 1. Resolution indexes of vanillic acid peak in relation of its adjacent peaks in the validated method.

\begin{tabular}{ccc}
\hline Extracts & Compounds & Resolution indexes \\
\hline \multirow{2}{*}{ Commercial water soluble dry powder } & Vanillic acid/A & 1.40 \\
& Vanillic acid/B & 1.53 \\
Commercial fluid & Vanillic acid/A & 1.48 \\
Commercial dry F\&C & Vanillic acid/B & 1.50 \\
& Vanillic acid/A & 1.51 \\
Bark & Vanillic acid/B & 1.42 \\
& Vanillic acid/A & 1.64 \\
\hline
\end{tabular}

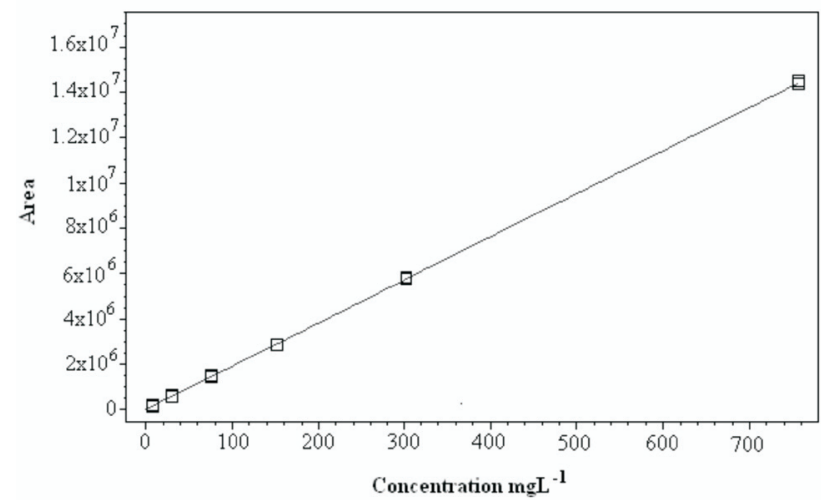

Figure 3. Calibration curve using standard solutions of vanillic acid at concentration of 756.6-7.566 mg. $\mathrm{L}^{-1}$, constructed to evaluate the linearity of the method. Regression equation of $\mathrm{y}=19000 \mathrm{x}+25200$ and correlation coefficient $(\mathrm{r})$ of 0.9999 .

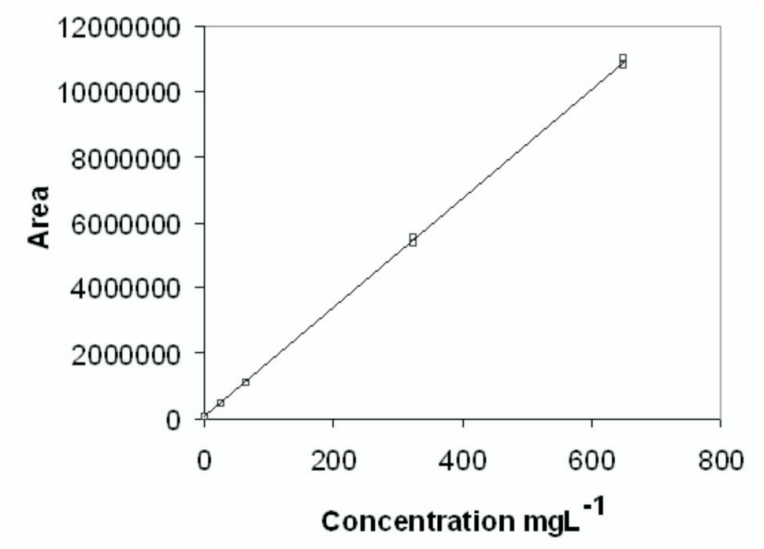

Figure 4. Calibration curve using standard solutions of vanillic acid at concentration of $649.9-2.600 \mathrm{mg} . \mathrm{L}^{-1}$, constructed to evaluate the reproducibility of the method. Regression equation of $y=16780 x+4353.2$ and correlation coefficient (r) of 0.9999 .

Table 2. Results obtained for the quantification of vanillic acid in P. olacoides commercial extracts.

\begin{tabular}{lc}
\hline \multicolumn{1}{c}{ Extracts } & $\begin{array}{c}\text { Vanillic acid content } \\
\text { (mg vanillic acid/g extract) }\end{array}$ \\
\hline $\begin{array}{l}\text { Commercial water soluble dry } \\
\text { powder }\end{array}$ & 0.31 \\
Commercial fluid & 0.02 \\
Commercial dry F\&C & 4.90 \\
\hline
\end{tabular}

\section{ACKNOWLEDGEMENTS}

The authors would like to thank Profa. Elizabeth Terán (In Memoriam) for her important contribution to this work, Anidro do Brasil Extrações Ltda (Botucatu-SP, Brazil) for technical and financial support, and $\mathrm{CNPq}$ for fellowships (Grant no. 500185/2006-9).

\section{REFERENCES}

Antunes E, Gordo WM, Oliveira JF, Hyslop S, de Nucci G 2001. The relaxation of isolated rabbit corpus cavernosum by the herbal medicine Catuama and its constituents. Phytother Res 15: 416-421.

Anvisa 2003. Guia para validação de métodos analíticos e bioanalíticos. Resolução-RE No 899. Diário oficial da republica federativa do Brasil: Brasília. http://www. anvisa.gov.br/legis/resol/2003/re/899_03re.htm,accessed April 2008.

Auterhoff H, Momberger B 1971. Lipophilic constituent of Muira puama. Arch Pharm Ber Dtsch Pharm Ges 304: 223-228.

Baby AR, Maciel CPM, Kaneko TM, Consiglieri VO, SalgadoSantos IMN, Velasco MVR 2005. Validation assay for total flavonoids, as rutin equivalents, from Trichilia catigua Adr. Juss (Meliaceae) (and) Ptychopetalum olacoides Bentham (Olacaceae) commercial extract. $J$ AOAC Int 88: 1015-1019.

Baby AR, Maciel CPM, Kaneko TM, Velasco MVR. 2006. UV spectrophotometric determination of bioflavonoids from a semisolid pharmaceutical dosage form containing Trichilia catigua Adr. Juss (and) Ptychopetalum olacoides Bentham standardized extract: analytical method validation and statistical procedures. J AOAC Int 89: 1532-11537.

Bebrevska L, Bravo L, Vandervoort J, Pieters L, Vlietinck A, Apers S 2007. Development and validation of an HPLC method for quality control of Pueraria lobata flower. Planta Med 73: 1606-1613.

Bucek EU, Fournier G, Dadoun H 1987. Volatile constituents of Ptychopetalum olacoides root oil. Planta Med 53: 231231.

Chang YC, Chang FR, Wu YC 2000. The Constituents of Lindera glauca. J Chin Chem Soc 47: 373-380.

Choi YH, Sertic S, Kim HK, Wilson EG, Michopoulos F, Lefeber AWM, Erkelen C, Kricun SDP, Verpoorte R 2005. Classification of Ilex species based on metabolomic 
fingerprinting using nuclear magnetic resonance and multivariate data analysis. J Agric Food Chem 53: 12371245.

Dogasaki C, Shindo T, Furuhata K, Fukuyama M 2002. Identification of chemical structure of antibacterial components against Legionella pneumophila in a coffee beverage. Yakugaku Zasshi 122: 487-494.

Drewes SE, George J, Khan F 2003. Recent findings on natural products with erectile-dysfunction activity. Phytochemistry 62: 1019-1025.

Elisabetsky E, Figueiredo W, Oliveira G 1992. Traditional amazonian nerve tonics as antidepressant agents: Chaunochiton Kappleri: a case study. J Herbs Spices Med Plants 1: 125-162.

ICH Steering Committee 1994. Validation of analytical procedures: methodology. ICH harmonised tripartite guideline. ICH steering committee: Geneva. http:// www.ikev.org/haber/stabilite/cd/08\%201.7\%20ICH\%20 Q2A\%20for\%20CD.pdf, accessed march 2009.

Ito Y, Hirayama F, Aikawa Y, Kondo H, Sagara K, Shoji J 1995. Constituents from Muira-puama (the roots of Ptychopetalum olacoides). Nat Med 49: 487-495.

Montrucchio DP, Miguel OG, Miguel MD, Monache FD, Carvalho JLS 2005. Componentes químicos e atividade antimicrobiana de Ptychopetalum olacoides Bentham. Visão Acad 6: 48-52.

Silva AL, Bardini S, Nunes DS, Elisabetsky E 2002. Anxiogenic properties of Phychopetalum olacoides Benth. (marapuama). Phytother Res 16: 223-226.

Silva AL, Piato AL, Ferreira JG, Martins BS, Nunes DS, Elisabetsky E 2007. Promnesic effects of Ptychopetalum olacoides in aversive and non-aversive learning paradigms. J Ethnopharmacol 109: 449-457.

Siqueira IR, Fochesatto C, Silva AL, Nunes DS, Battastini AM, Elisabetsky E, Netto CA 2003. Ptychopetalum olacoides, a traditional Amazonian nerve tonic, possesses anticholinesterase activity. Pharmacol Biochem Be 75: 645-650.

Siqueira IR, Fochesatto C, Torres ILS, Silva AL, Nunes DS, Elisabetsky E, Netto CA 2007. Antioxidant activities of Ptychopetalum olacoides ("muirapuama") in mice brain. Phytomedicine 14: 763-769.

Toyota A, Ninomiya R, Kobayashi H, Kawanish K, Uhara Y, Kato A, Hashimoto Y 1979. Studies of Brazilian crude drugs 1 muirapurama. Shoyakugaku Zasshi 33: 57-64.

United States Pharmacopeial Convention 2007.Validation of compendial methods. In United States Pharmacopeia 23, Chapter 1225. The United States Pharmacopeial Convention Inc: Rockville, 1982-1984.

Wang J, Lou Z, Zhu Z, Chai Y, Wu Y 2005. A rapid highperformance liquid chromatographic method for quantitative analysis of antidiabetic-active components in Anemarrhena asphodeloides rhizomes. Chromatographia 61: 633-636. 